\title{
Identifikasi Biodeteriogen Sebagai Langkah Awal Konservasi Benda Cagar Budaya
}

\author{
Moh. Habibi \\ Balai Konservasi Borobudur \\ Email : habib1_m@yahoo.com
}

\begin{abstract}
Abstrak : Indonesia mempunyai Benda Cagar Budaya (BCB) yang berlimpah. BCB tersebut dapat mengalami degradasi disebabkan mikroorganisme. Penelitian ini bertujuan untuk memberikan pengetahuan mengenai teknik molecular yang digunakan untuk deteksi biodeteriogen pada benda cagar budaya. Teknik Molekuler yang dapat digunakan adalah Fingerprinting, meliputi DGGE (Denaturing Temperature Gradient Gel Electrophoresis), SSCP (Single Strand Conformation Polymorphism), ARDRA (Amplified rDNA Restriction Analysis), dan Clone Library. Teknik ini mempunyai beberapa kelebihan, seperti tingkat presisi yang tinggi, lebih cepat digunakan, dapat digunakan untuk mengetahui peran biodeteriogen pada lingkungan.
\end{abstract}

Kata Kunci : Benda Cagar Budaya, Biodeteriogen, Biologi Molekuler.

\begin{abstract}
Indonesia has a lot of clutural heritage properties (CHP). The CHP may be degraded due to microorganisms. This study purposes provide knowledge about the molecular techniques used for the detection of biodeteriogen on cultural heritage properties. Molecular techniques that can be used are Fingerprinting, covering DGGE (Denaturing Temperature Gradient Gel Electrophoresis), SSCP (Single Strand conformation polymorphism), ARDRA (Amplified rDNA Restriction Analysis), and Clone Library. This technique has several advantages, such as high levels of precision, faster to use, can be used to determine the role biodeteriogen on the environment.
\end{abstract}

Keyword : Cultural Heritage Properties, Biodeteriogen, Molecular Biology

\section{Pendahuluan}

\section{A. Latar Belakang}

Indonesia memiliki ribuan cagar budaya yang tersebar di berbagai daerah, baik berupa Benda Cagar Budaya (BCB), Bangunan Cagar Budaya, Struktur Cagar Budaya, Situs Cagar Budaya, dan Kawasan Cagar Budaya. Seperti yang telah diketahui bersama bahwa cagar budaya dibedakan menjadi cagar budaya bergerak dan tidak bergerak. Cagar budaya bergerak adalah cagar budaya yang dapat dipindah-pindahkan dari satu tempat ke tempat lainnya, sedangkan cagar budaya tidak bergerak adalah cagar budaya yang tidak dapat dipindah-pindahkan dan umumnya bersifat monumental. Berdasarkan data yang dimiliki oleh Direktorat Pelestarian Cagar Budaya dan Permuseuman (PCBM) pada tahun 2013, jumlah cagar budaya di Indonesia mencapai angka 66.513, yang terdiri dari 54.398 Cagar Budaya bergerak dan 12.115 Cagar Budaya tidak bergerak. Dari jumlah tersebut, cagar budaya yang telah dikonservasi baru sejumlah 146 Cagar Budaya.

Salah satu permasalahan konservasi benda cagar budaya yang sering dihadapi adalah adanya proses pelapukan yang disebabkan oleh biodeteriogen, baik itu bakteri, algae, lichen, maupun lumut. Mikroorganisme tersebut biasanya membentuk koloni pada permukaan Benda Cagar Budaya (BCB), sehingga selain menimbulkan pelapukan juga menyebabkan berkurangnya nilai estetika $\mathrm{BCB}$, seperti terjadinya perubahan warna Benda Cagar Budaya. Mikroorganisme merupakan organisme yang dominan di lapisan Biosfer saat ini dengan perkiraan jumlah sel total mikroorganisme 4-6 × $10^{30}$ (Simon \& Rolf, 2011). Mempunyai kemampuan adaptasi yang sangat luar biasa hebat terhadap berbagai macam kondisi lingkungan. Habitat mikroorganisme meliputi daratan dan lautan. Selain itu, mikroorganisme memiliki peranan penting dalam proses ekologi dan biogeokimia.

Mikroorganisme pada bangunan cagar budaya berpeluang menyebabkan terjadinya proses perubahan warna, pembentukan biofilm, dan crust, biomineralisasi, dan degradasi material organic dan inorganic pada benda cagar budaya (De Felice et al., 2010). Mekanisme yang terjadi adalah produksi asam dan basa, perubahan komponen permukaan, penyerapan panas, peningkatan retensi air, dan penetrasi ke dalam struktur batuan secara langsung (Kiel \& Gaylarde, 2006). Oleh karena itu, hal utama dan pertama yang harus dilakukan sebelum 
melakukan restorasi dan konservasi adalah melakukan identifikasi mikroorganisme yang menyebabkan biodeteriorasi pada bangunan cagar budaya untuk mengetahui pengaruh mikroorganisme terhadap BCB. Beberapa pertanyaan yang perlu dijawab ketika hendak melakukan konservasi adalah 1) Mikroorganisme apa yang terdapat dalam BCB?, 2) Apa peran mikroorganisme tersebut?, 3) Bagaimana mikroorganisme tersebut merespon perubahan lingkungan, 4) Apa hubungan peran mikroorganisme dengan lingkungannya?

Langkah kedua yaitu mengetahui jumlah mikroorganisme, aktivitas dan peran mikroorganisme pada proses biodeteriorasi. Langkah terakhir adalah menggunakan informasi mikroorganisme yang telah diperoleh untuk menentukan strategi yang akan digunakan dalam konservasi dan preservasi Bangunan Cagar Budaya. Oleh karena itu, analisis biodiversitas koloni mikroba pada bangunan cagar budaya sangat lah penting sebagai langkah awal (Preliminary step) konservasi dan preservasi BCB. Untuk mengidentifikasi mikroba diperlukan metode dan teknik identifikasi yang benar dan tepat sehingga dihasilkan data yang akurat dan valid.

\section{Pembahasan}

\section{A. Metode Kultur}

Metode dan teknik identifikasi mikroba pada bangunan cagar budaya telah berkembang dengan pesat. Mulai dari metode kultur sampai dengan teknik yang memanfaatkan molekuler. Di bawah ini akan dijelaskan mengenai beberapa teknik identifikasi mikroba pada BCB.

Metode kultur telah lama digunakan. Metode ini menggunakan perantara medium selektif untuk menumbuhkan mikroba. Metode kultur meliputi penumbuhan mikroba pada medium kultur, pengamatan morfologi mikroba di bawah mikroskop dan penghitungan kuantitas koloni dengan menggunakan Plate Count atau Colony Counter. Sedangkan untuk mengetahui aktifitas fisiologi mikroba dengan menggunakan Colony Forming Unit (CFU).Metode kultur memiliki kelebihan dan kelemahan. Kelebihan metode kultur adalah berguna untuk mengetahui fisiologi dan biokimia mikroba. Sedangkan kelemahan teknik ini adalah tidak diperolehnya informasi kompleks biodiversitas koloni mikroba, membutuhkan jumlah sampel yang banyak, memerlukan waktu lebih dll. Dan pada kenyataannya, hanya sekitar 0,1-1\% mikroorganisme yang ada di alam yang dapat dikembang biakkan dalam kultur medium laboratorium (Schabereiter-Gurt-ner et al., 2001). Sisanya yang 99\% berada dalam kondisi anabiosis, mampu tetap hidup tetapi tidak dapat dikultur (Viable But Non Culturable/VBNC).

Jika spesies yang akan dikultur merupakan spesies yang sedikit informasinya, maka yang perlu dilakukan terlebih dahulu adalah optimasi komposisi medium. Karena setiap spesies mikroorganisme membutuhkan kadar kadar dan komposisi medium yang berbeda-beda. Di dalam medium kultur terdapat komponen karbohidrat, protein, dan vitamin yang memiliki konsentrasi berbeda bagi setiap jenis mikroorganisme. Beberapa kendala di atas dapat mengurangi informasi biodiversitas ekosistem mikroorganisme yang kompleks, seperti pada bangunan cagar budaya.

\section{B. Teknik Biologi Molekular}

Ilmu Molekuler adalah salah satu metode yang berkembang pesat saat ini dalam ilmu Biologi. Teknik ini berdasarkan perbedaan atau keunikan urutan basa nitrogen pada tiap-tiap individu dalam satu jenis. Karena pada dasarnya setiap individu dalam satu jenis/spesies memiliki urutan rantai DNA (Deoxyribo Nucleic Acid) yang khas dan berbeda. DNA sendiri terdiri dari empat macam basa nitrogen, yaitu basa Adenin, Cytosin, Guanin, dan Timin. DNA mengkode dan menghasilkan asam amino tertentu, sesuai dengan urutan basa nitrogen yang dibawa oleh DNA. Misalnya urutan basa ATG akan mengkode asam amino Methionin. Selanjutnya antara asam amino yang satu dengan lainnya bergabung membentuk protein. Protein akan mempengaruhi fisiologis, metabolism dan morfologi organisme. Protein terbanyak yang berpengaruh terhadap fisiologis berupa enzim, struktur katalitik spesifik tertentu yang berfungsi dalam rangkaian urutan metabolisme.

Sepertiyang telah dijelaskan sebelumnya, sebagian besar mikroorganisme di alam tidak dapat dikulturkan dalam skala laboratorium dikarenakan keterbatasan informasi. Oleh karena itu, identifikasi mikroorganisme dengan dikulturkan terlebih dahulu hanya menyediakan sedikit informasi mengenai biodiversitas mikroorganisme yang berkembang di bangunan cagar budaya. Teknik yang dapat digunakan dan berkembang saat ini adalah 

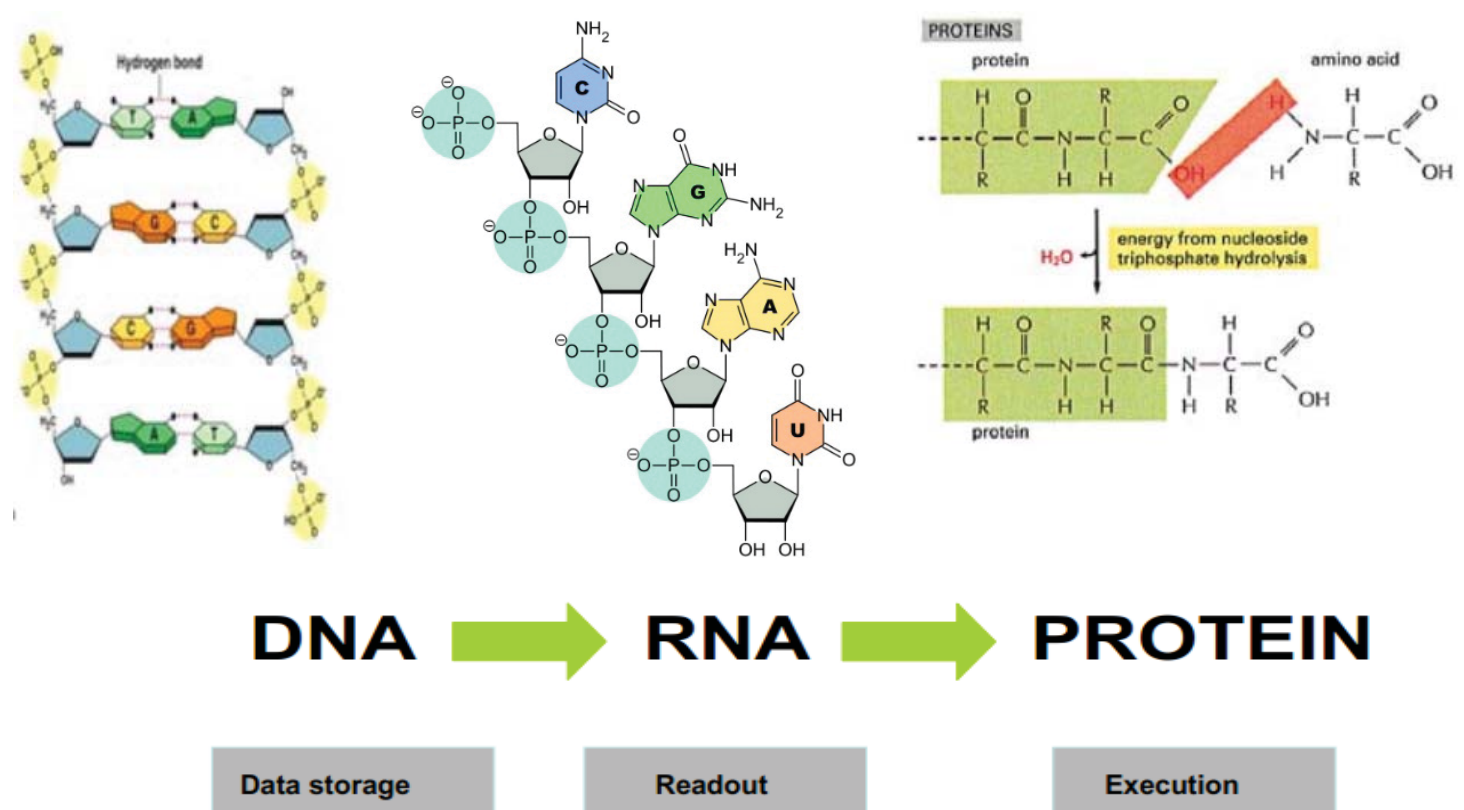

\section{Readout}

Execution

Gambar 1. Dogma Sentral Biologi.

metagenomik, yaitu metode yang digunakan untuk mempelajari populasi kompleks mikroorganisme dengan menggunakan biologi molecular. Teknik metagenomik dapat mengisolasi material genetic sampel di habitatnya secara langsung, sehingga informasi genetic dari sampel dapat diketahui sepenuhnya. Untuk melakukan teknik ini diperlukan beberapa tahapan-tahapan, yaitu:

\section{Isolasi DNA dan Amplifikasi Gen Target}

Untuk melakukan analisis biologi molekuler, hal pertama yang harus dilakukan adalah mengisolasi DNA atau gen target dari mikroorganisme yang menempati benda cagar budaya. Karena DNA atau gen terletak di dalam inti sel (nucleus) dan mitokondria. Jumlah minimal DNA template yang harus diperoleh adalah $>2 \mathrm{mg}$. Jika DNA template yang didapatkan kurang dari $1 \mathrm{mg}$ maka akan menyebabkan kurang akuratnya proses identifikasi mikroorganisme. Selain itu, sampel DNA yang diperoleh harus bersih dari kontaminan.

Teknik molekuler yang banyak digunakan yaitu perbanyakan dengan PCR (PCR-amplification). Gen yang diamplifikasi biasanya adalah gen rRNA (ribosomal RNA). rRNA merupakan salah satu marker yang paling banyak digunakan untuk mengidentifikasi sampel mikroorganisme pada suatu lingkungan. Hal ini dikarenakan beberapa factor seperti yang diungkapkan oleh Rastogi dan Sani, 2011, yaitu (1) dapat ditemukan pada organisme prokariotik dan eukariotik, (2) dipertahankan secara struktural dan fungsional, (3) memiliki daerah yang dipertahankan (bighly conserved) dan daerah variable (variable region). Gen rRNA memiliki dua subunit yang sering digunakan, subunit 16S rRNA untuk analisis prokariotik dan subunit $18 \mathrm{~S}$ rRNA untuk analisis eukariotik. Deteksi dan identifikasi bakteri menggunakan 16S rRNA telah digunakan pada lukisan Mural di Gereja St. Martin, Jerman (Gorbushina et al., 2004), Saint Catherine Chapel di Kastil Herberstein, Austria (Gurtner et al., 2000), Roman Necropolis Carmona di Spanyol (Smerda et al., 2006), makam warga mesir di delta nil timur, Mesir (Abdel Halim et al., 2013) dll.

Penanda molekuler yang banyak digunakan untuk identifikasi jamur (fungi) adalah ITS (Internal Transcribed Spacer). Secara structural, gen ITS terletak diantara 16S dan 28S rRNA serta terdiri dari internal non-coding regions ITS1, ITS2, dan gen 5,8S rRNA. Region tersebut memiliki kelebihan yaitu, memiliki daerah conserved yang tinggi (bighly conserved region), memiliki similaritas dengan organisme dengan jarak evolusi yang lumayan jauh, dan mempunyai sekuen dengan variabilitas genetik yang tinggi. Dengan pertimbangan kelebihan tersebut, penanda ITS dapat digunakan untuk determinasi genus dan spesies. Keberadaan gen ITS pada jamur sangat berlimpah, sehingga dapat meningkatkan sensitivitas reaksi PCR (Ciardo et al., 2010).

Produk amplifikasi PCR dari DNA lingkungan dapat dianalisis dengan menggunakan 1) genetic 


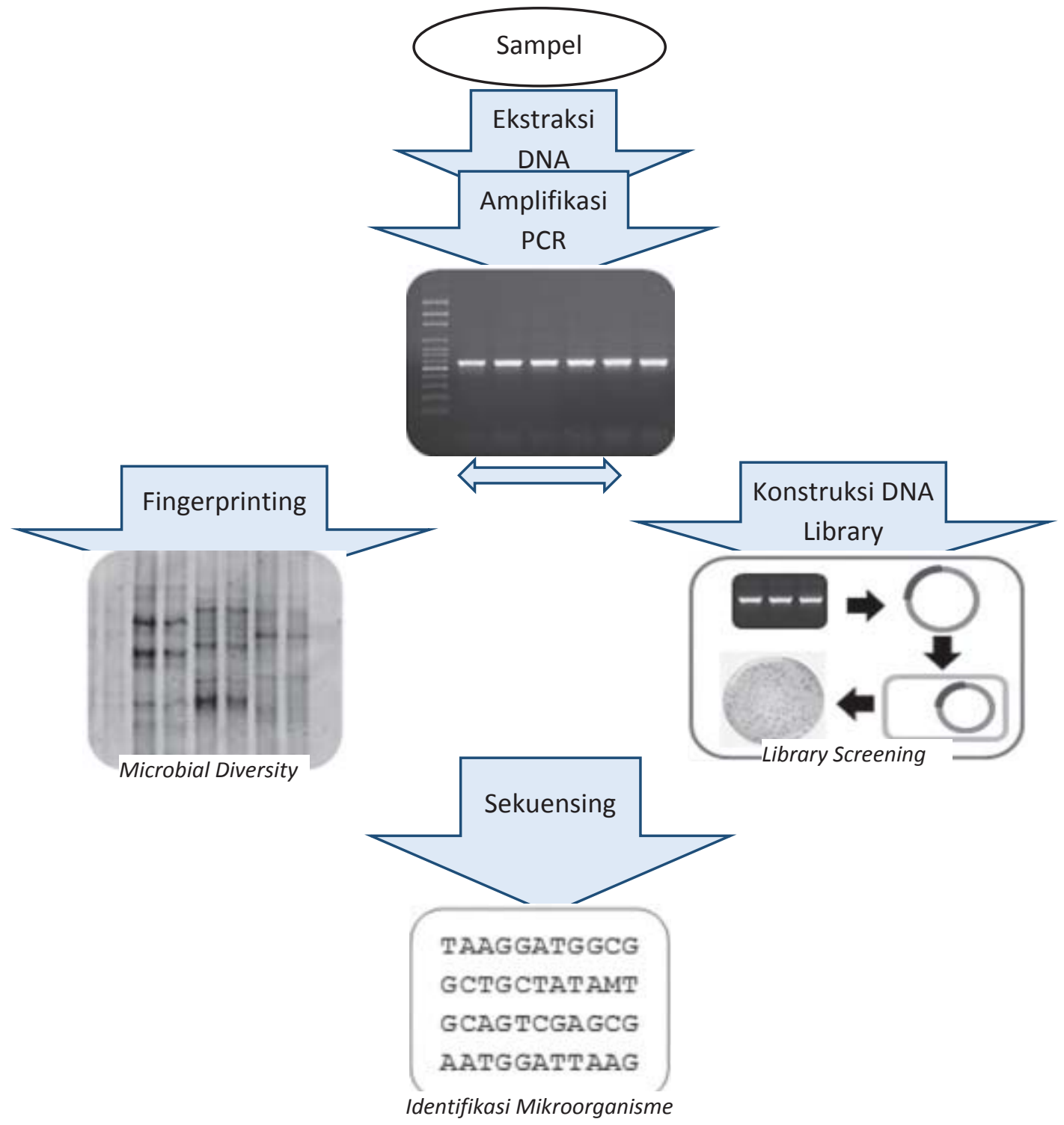

Gambar 2. Alur identifikasi Mikroorganisme pada bangunan cagar budaya menggunakan Molekuler.

fingerprinting, 2) clone library, 3) kombinasi genetic fingerprinting dan clone library

\section{Teknik Fingerprinting}

Teknik fingerprinting berdasarkan pada analisis elektroforetik dari produk PCR. Terdapat beberapa cara atau metode yang dapat digunakan untuk mendapatkan fingerprint mikoroorganisme dari lingkungan, yaitu DGGE/TGGE (Denaturing/Temperature Gradient Gel Electrophoresis), SSCP (Single Strand Conformation Polymorphism), ARDRA (Amplified rDNA Restriction Analysis), T-RFLP (Terminal Restriction Fragment Length Polymorphism), dan ARISA (Automated Ribosomal Intergenic Spacer Analysis). Teknik fingerprinting dapat juga digunakan untuk mengetahui diversitas komunitas mikroorganisme. Prosedur umum yang digunakan pada teknik ini adalah isolasi DNA, amplifikasi gen dengan PCR, dan produk PCR dianalisis dengan elektroforesis pada gel agarose atau poliakrilamide. Kelebihannya adalah teknik ini tidak hanya dapat diaplikasikan terhadap mikroorganisme yang dapat dikulturkan, tetapi juga dapat diaplikasikan untuk mengetahui diversitas mikroorganisme yang tidak dapat dikulturkan serta mikroorganisme inaktif.

Teknik fingerprinting DGGE merupakan teknik yang paling banyak diterapkan pada biodeteriogen benda cagar budaya (Ripka et al., 2006). Prinsip kerja metode ini adalah dengan menggunakan keadaan melting rantai ikatan ganda DNA. Rantai ikatan ganda DNA dapat mencapai kondisi melting dengan pengaruh bahan kimia tertentu (Urea dan Formamide) atau pengaruh suhu., yang juga disebut TGGE. Jika kondisi melting tercapai, maka ikatan rantai DNA akan terputus menjadi 


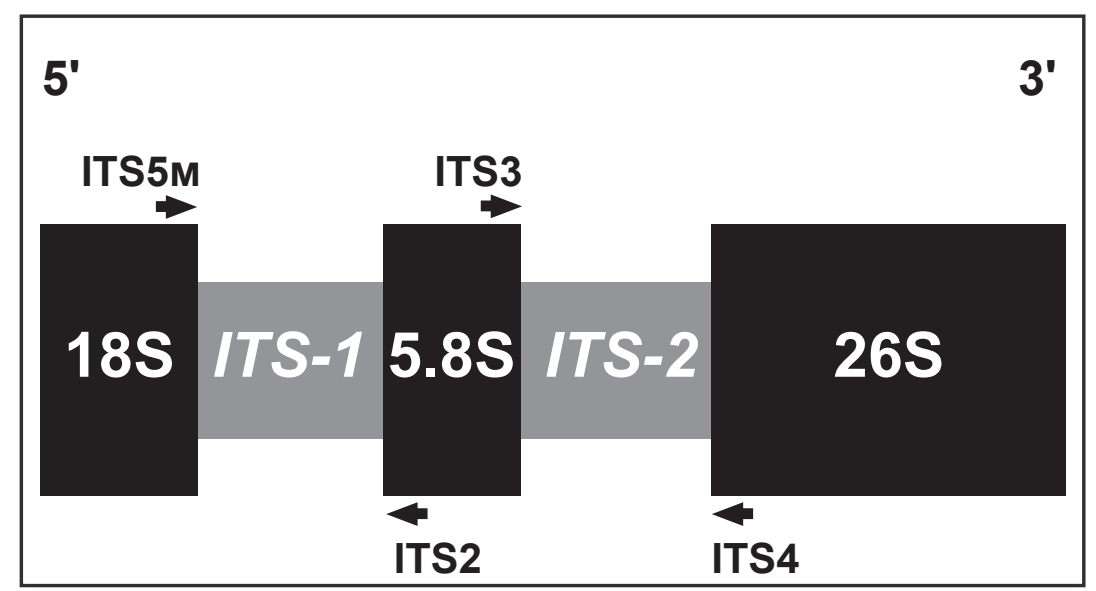

Gambar 3. Struktur gen ITS (Internal Transcribed Spacer).

beberapa bagian dengan panjang kurang lebih 25 pasang basa. Tempat putusnya rantai DNA ini disebut melting point. Melting point bersifat khas dan spesifik pada tiap individu mikroorganisme. Perbedaan cetakan melting point inilah yang digunakan sebagai dasar identifikasi mikroorganisme.

Metode DGGA digunakan oleh Ripka et al. (2006) untuk mengidentifikasi Jenis mikroorganisme pada lukisan dinding di gereja Chaterine, Styria, Austria dan gereja Virgil, Vienna, Austria. Penelitian tersebut berhasil mengungkap jenis mikroorganisme yang berada di lukisan dinding kedua gereja tersebut.

Berdasarkan hasil analisis menggunakan teknik DGGE di atas, dapat diketahui bahwa $H$. trueperi, $H$. literalis, dan $H$. karajensis menunjukkan pita tunggal yang dominan pada posisi yang sama. Sedangkan isolate S3, S4, dan S21 menunjukkan pola pita yang identic. Sedangkan isolate $\mathrm{I7}, \mathrm{S} 22, H$. balophilus, $H$. locisalis, dan $H$. salinus menunujukkan profile yang unik serta berbeda dari strain yang lain.

Selanjutnya adalah metode ARDRA. Prinsip metode ini adalah dengan memanfaatkan pengenalan sisi enzim restriksi pada rantai DNA. Sisi enzim restriksi sangat spesifik antara satu organisme dengan yang lainnya. Tahapanya adalah gen RNA ribosom (16S rRNA dan $18 \mathrm{~S}$ rRNA) dari lingkungan di amplifikasi dengan PCR. Selanjutnya produk PCR di restriksi dengan enzim endonuclease. Hasil pemotongan tersebut kemudian di separasi pada gel agarose. Teknik ini digunakan untuk menentukan biodiversitas dari biodeteriogen yang terletak pada beberapa monument yang terbuat dari batu di Italy (Tomaselli et al., (2000)). Penelitian biodiversitas dari biodeteriogen pada monument batuan ini dapat membantu konservator mengklasifikasikan biodeteriogen berdasarkan habitat tempat hidupnya. Metode ini diawali dengan pemurnian sampel yang diperoleh dari beberapa monument batu di Italy. Setelah didapatkan spesies murni, kemudian dilakukan metode restriksi ARDRA dengan menggunakan enzim restriksi Hinf I 16S rDNAs. Hasil restriksi dapat dilihat pada gambar di bawah ini

Berdasarkan hasil restriksi tersebut dapat dibuat dendrogam hubungan kekerabatan antar spesies yang ditemukan. Seperti terlihat pada bagan dendrogam di bawah ini.

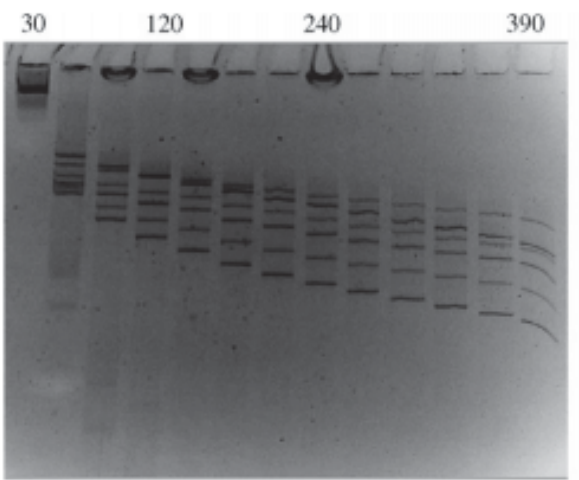




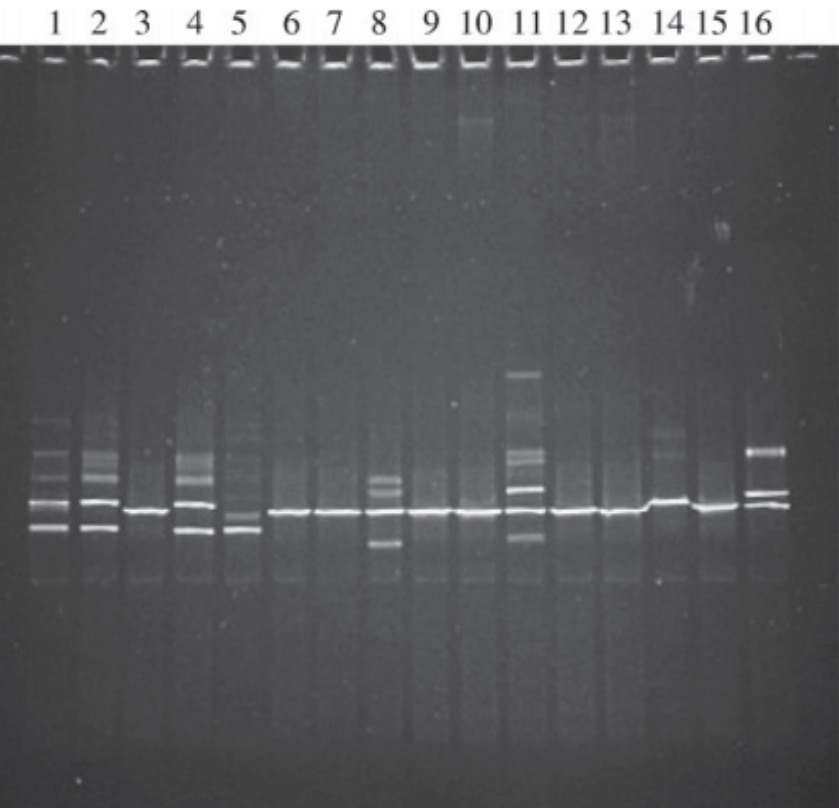

Gambar 5. Profiles DGGE dari spesies Halobacillus di lukisan dinding. Lajur 1: Isolat S3; Lajur 2: Isolat S4; Lajur 3: Isolat S20; Lajur 4: Isolat S21; Lajur 5: Isolat S22; Lajur 6: Isolat K3-1; Lajur 7: Isolat I3: Lajur 8: Isolat 17; Lajur 9: Isolat I3R; Lajur 10: Isolat I3A; Lajur 11: Halobacillus halophillus; Lajur 12: H. trueperi ; Lajur 13: H. litoralis; Lajur 14: H. locisalis; Lajur 15: H. karajensis; Lajur 16: H. salinus (Ripka et al. (2006))

Teknik identifikasi mikroorganisme pada bangunan cagar budaya selanjutnya adalah SSCP (Single Strand Conformation Polymorphism). Metode ini berdasarkan pada prinsip pemisahan fragmen DNA pada gel polyacrylamide. Fragmen DNA dipisahkan berdasarkan lipatan DNA pada teknik ini. Metode SSCP tidak membutuhkan primer yang banyak mengandung GC dan tidak melalui gel gradient. Kelemahan dari metode ini adalah fragmen DNA yang dipisahkan hanya sebatas pada 150-400 pasang basa. Metode SSCP digunakan oleh Morales (2006) untuk mengidentifikasi biofilm pada bangunan cagar budaya Uxmal di Mexico. Penelitian ini berhasil dilakukan tanpa perlu menumbuhkan sampel yang diperoleh di laboratorium. Karena tidak semua mikroorganisme dapat dikultur di laboratorium, maka teknik ini dapat diaplikasikan kepada mikroorganisme yang tidak dapat dikultur.

\section{E. Teknik Konstruksi Clone Library}

Metode ini telah banyak digunakan untuk menganalisis produk PCR sampel dari lingkungan. Clone library memiliki beberapa tahapan, yaitu 1) Isolasi DNA, 2) fragmentasi dan insersi DNA pada vector, 3) Kloning DNA dan transformasi pada host cell (sel inang) yang sesuai, 4) seleksi clone library, 5) analisis bioinformatik. Langkah terpenting adalah pemilihan vector dan sel inang yang sesuai. Vektor dalam hal ini dapat berupa bakteri ataupun virus. Contoh vector dalam hal ini adalah seperti plasmid DNA (dapat diinsersi kurang dari 20 pasang basa), kosmid dan fosmid (diantara 25 sampai 35 pasang basa), bacterial artificial chromosome (lebih dari 40 pasang basa).Hal penting lainnya pada clone library adalah memilih sel inang yang baik. Sel inang yang biasa digunakan adalah Eschericia coli, sel inang yang lain yang

\section{$\begin{array}{llllllllllllllllllll}\mathrm{L} & 2 & 3 & 4 & 5 & 6 & 7 & 8 & 9 & 10 & 11 & 12 & 13 & 14 & 15 & 16 & 17 & 18 & 19 & \mathrm{~L}\end{array}$}

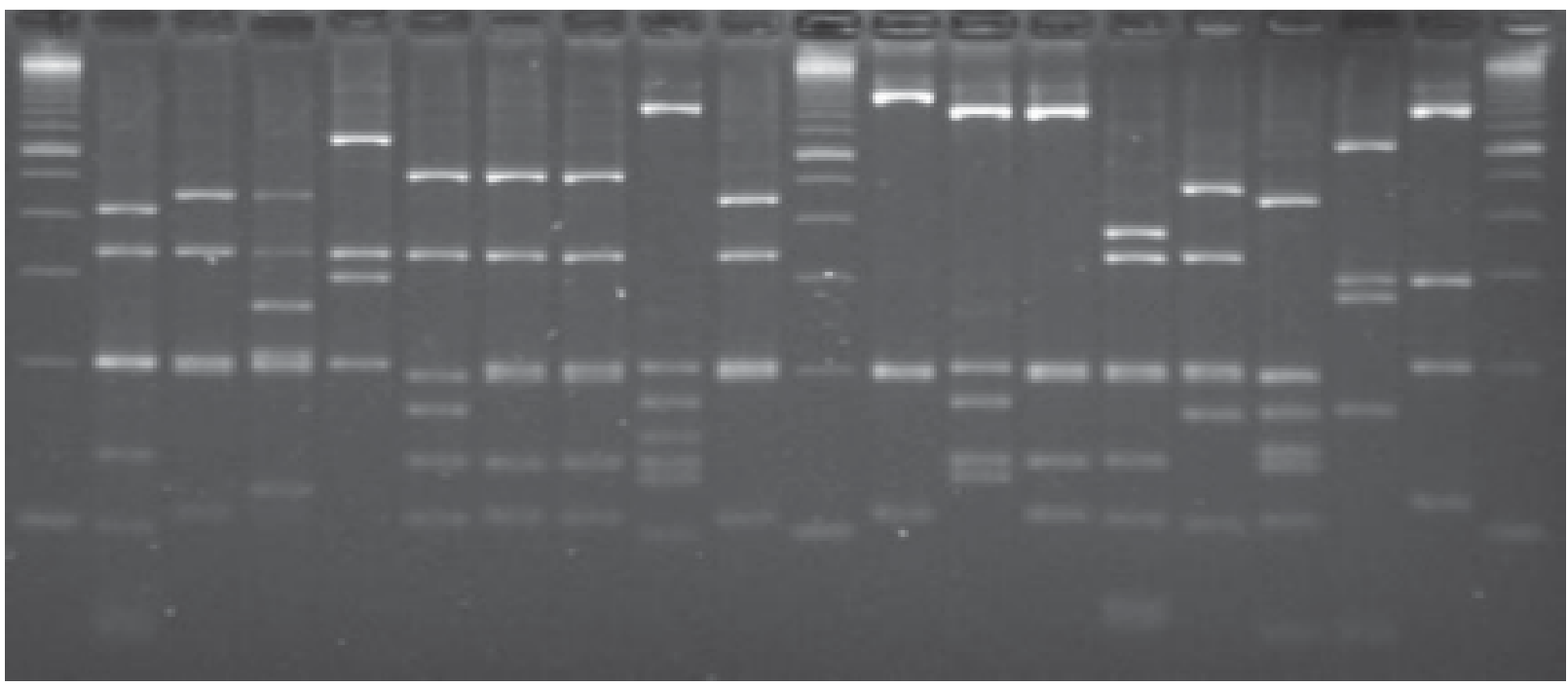

Gambar 6. Hasil restriksi enzim Hinf I 16S rDNAs. L: DNA Ladder; 2: C6; 3: C11; 4: C9; 5: C8; 6: Li-f; 7: Li-m; 8: Vol; 9: Peg; 10: Mu-2; 12: Mu-sc; 13: Mu-pl; 14: Mu-C; 15: Bg-C; 16: PCC 6307; 17: PCC 6308; 18: PCC 73106; 19 : PCC 6306 (Tomaselli et al., 2000). 


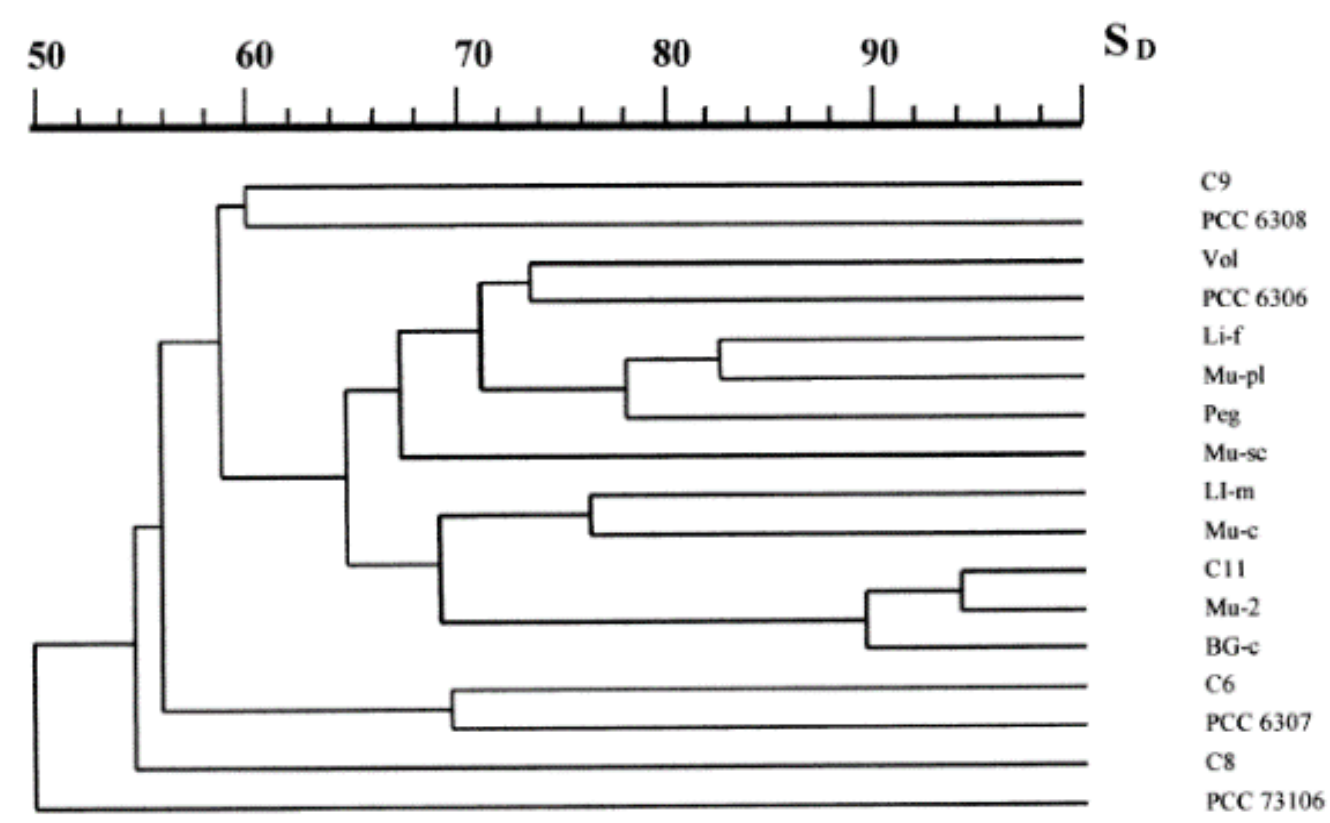

Gambar 7. Dendrogam UPGMA dari Cyanobacterial 16S ARDRA yang dikombinasikan dengan 5 enzim endonuclease. SD (Dice Similarity Coefficient \%), menunjukkan koefisien similaritas.

digunakan adalah Rhizobium leguminosarum, Streptomyces lividans, dll.

Teknik Clone library digunakan oleh Coutinho et al., (2013) untuk mengungkap keberadaan biodeteriogen pada bangunan kerajaan nasional Pena di Portugal. Kerajaan Pena terbuat oleh keramik. Keramik kerajaan ini di tutupi oleh lapisan biofilm yang berwarna hijau dan dapat membahayakan atau menyebabkan kerusakan pada keramik bangunan. Selain menemukan spesies mikroorganisme, penelitian ini juga berhasil mengungkap hubungan kekerabatan antar spesies yang ditemukan

\section{Kesimpulan}

Metode identifikasi mikroorganisme yang terletak pada benda cagar budaya diperlukan untuk langkah awal konservasi. Dengan diketahuinya identitas mikroorganisme yang ada, dapat dilakukan penanganan konservasi benda cagar budaya dengan baik dan aman. Teknik identifikasi mikroorganisme dapat dilakukan dengan dua cara, yaitu konvensional (kultur) dan molekuler. Metode molekuler mempunyai beberapa kelebihan daripada kultur, membutuhkan waktu yang lebih cepat, tidak membutuhkan sampel yang banyak, sampel tidak harus ditumbuhkan di medium terlebih dahulu, dan lain-lain. Teknik molekuler yang telah diaplikasikan untuk identifikasi mikroorganisme pada benda cagar budaya adalah Fingerprinting, meliputi DGGE (Denaturing Gradient Gel Electhrophoresis), SSCP (Single Strand Conformation Polymorphism), ARDRA (Amplified rDNA Restriction Analysis), dan Clone Library.
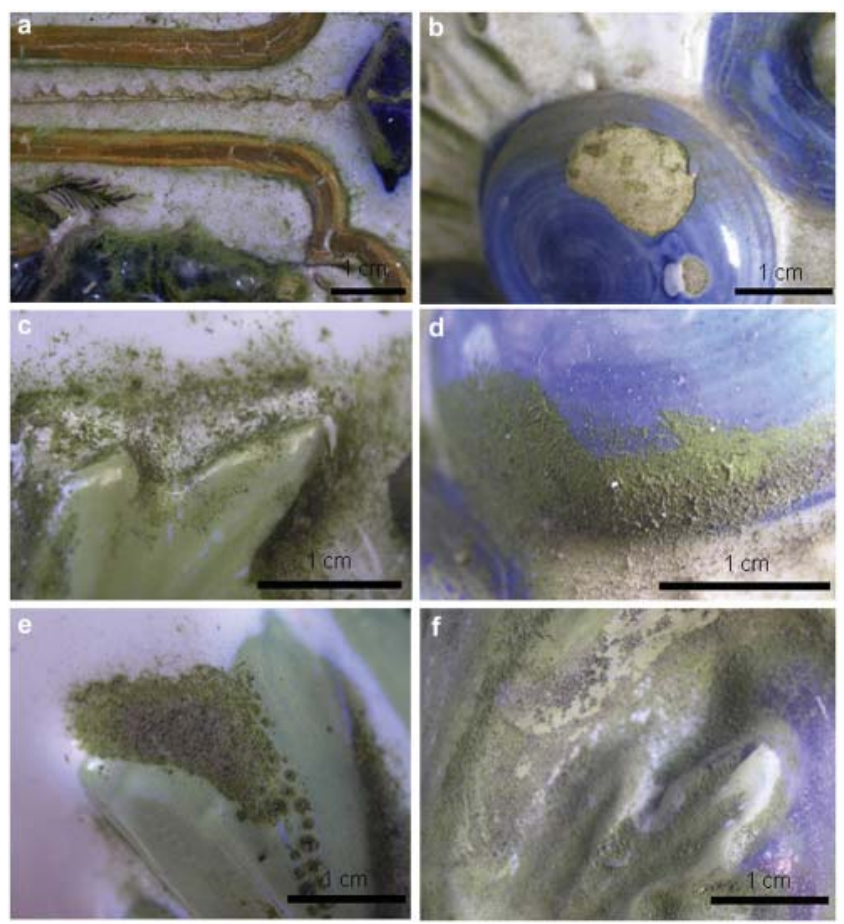

Gambar 8. Kerusakan keramik bangunan Kerajaan Nasional Pena yang disebabkan oleh lapisan Biofilm Mikroorganisme. 


\section{DAFTAR PUSTAKA}

Abdel-Haliem MEF, Sakr AA, Ali MF, Ghaly MF, Sohlenkamp C (2013) Characterization of Streptomyces isolates causing colour changes of mural paintings in ancient Egyptian tombs. Microbiol Res 168: 428-437.

Ciadro DE, Lucke K, Imhof A, Bloemberg GV, Bottger EC (2010) Systematic internal transcribed spacer sequence analysis for iden -tification of clinical mold isolates in diagnostic mycology: a 5-year study. J Clin Microbiol48 : 2809-2813

Coutinho ML, Miller AZ, Gutierrez-Patricio S, Hernandez-Marine M, Gomez-Bolea A, Rogerio-Candelera MA, Philips AJL, Jurado V,Saiz-Jimenez C, Macedo MF (2013) Microbial communities on de -teriorated artistic tiles from Pena National Palace (Sintra, Portugal). Int Biodeter84 : 322-332.

De Felice B, Pasquale V, Tancredi N, Scherillo S, Guida M (2010) Ge-netic fingerprint of microorganisms associated with the deterioration of an historical tuff monument in Italy. J Genet 89 : 253-257.

Gorbushina AA, Heyrman J, Dornieden T, GonzalezDelvalle M, Krumbein WM, Laiz L, Petersen K, Saiz-Jimenez C, Swings J (2004) Bacterial and fungal diversity and biodeterioration problems in mural painting environments of St. Martins church (Greene-Krei -ensen, Germany). Int Biodeter Biodegr53 : 13-24.

Gurtner C, Heyrman J, Piñar G, Lubitz W, Swings J, Rölleke S (2000) Comparative analyses of the bacterial diversity on two different biodeteriorated wall paintings by DGGE and $16 \mathrm{~S}$ rDNA sequence analysis. Int Biodeter Biodegr46 : 229-239.
Kiel G, Gaylarde CC (2006) Bacterial diversity in biofilms on external surfaces of historic buildings in Porto Alegre. World J Microb Biot22 : 293-297.

Morales B. 2006. Cyanobacterial diversity and ecology on historic monuments in Latin America. Latinoam Microbiol 48 (2): 188-195

Rastogi G, Sani RS (2011) Molecular techniques to asses microbial community structure, function and dynamics in the environment. In Microbes and microbial technology: agricultural and environmental applications . Ahmad I, Ahmad F, Pichtel J, eds, pp 29-57. Springer, New York.

Ripka K, Denner EBM, Michaelsen A, Lubitz W, Piñar G (2006) Mo-lecular characterization of Halobacillus strains isolated from different medieval wall paintings and building materials in Austria. Int Bioder Biodegr 58 : 124-132.

Schabereiter-Gurtner C, Pinar G, Lubitz W, Rölleke S (2001) An ad-vanced strategy to identify bacterial communities on art objects. J Microbiol Methods $45: 77-87$

Simon C, Rolf D (2011) Metagenomic analyses: past and future trends. Appl Environ Microbiol 77 : 11531161.

Smerda J, Sedlácek I, Pácová Z, Krejcí E, Havel L (2006) Paenibacillus sepulcri sp. nov., isolated from biodeteriorated mural paintings in the Servilia tomb. Int J Sys Evol Microbiol 56: 2341-2344.

Tomaselli L, Lamenti G, Bosco M, Tiano P (2000) Biodiversity of photosynthetic microorganisms dwelling on stone monuments. Int Biodeter Biodegr 46 : 251-258. 